\title{
Technical Competency of Construction Manager in Malaysian Construction Industry
}

\section{${ }^{1}$ Siti Khalijah Yaman, ${ }^{2}$ Abd Halid Abdullah, ${ }^{3}$ Hairuddin Mohammad and ${ }^{4}$ Fadzil Hassan}

\author{
${ }^{1,2,3}$ Faculty of Civil and Environmental Engineering, Universiti Tun Hussein Onn Malaysia \\ ${ }^{4}$ Faculty of Architecture, Planning \& Surveying, Universiti Teknologi MARA \\ ${ }^{1}$ khalijah@uthm.edu.my; ${ }^{2}$ abdhalid@uthm.edu.my; ${ }^{3}$ hirudin@uthm.edu.my; \\ 4padzil037@salam.uitm.edu.my
}

\section{Keywords:, Construction management, construction manager, technical competency}

\begin{abstract}
Primarily due to contractors' faults, construction industries in Malaysia have been facing problems such as delays, wastages, cost overruns and others. Inability of construction manager (CM) to efficiently manage construction projects is the major contribution to projects' failure, and the lack of terms of reference on the technical competency for CM are believed to be the major setback. This paper reports the results of a preliminary study which was carried out to identify the technical competencies of CM. Exploratory mixed research methods were selected by employing qualitative and quantitative approaches. Multi-layered thematic analysis was embedded into literature analysis to maintain reliability and then validate through structured interviews. It was found that $\mathrm{CM}$ requires several technical competencies including managing staff, materials, labours, plants, sub-contractors, safety, money, quality, time, environment, administration, pre-construction, closeout and handover, responsibility to other parties, computer literacy, and administration of construction contract. Hence, the technical competencies for CM are believed to be exhaustive and holistic in singling out the appropriate technical knowledge and skills, and bring about numerous advantageous towards technically competent CM.
\end{abstract}

\section{Introduction}

Malaysian construction industry (MCI) is renowned as one of the important industries and a significant contributor towards the country's growth domestic product. Furthermore, construction industry also acts as a multiplier for other important industries and engaging many value chain stakeholders [1]. However, the progression of MCI has been hampered by a considerable number of problems such as delays, wastages, cost overruns and others which uplifted by a few researchers [24]. It has been observed that the recurring theme of exceeding time and budget, not according to the specifications and quality was particularly due to the contractors' fault which primarily occurred during the physical implementations of a construction project [3-6].

Currently, there are over 64,000 of contractors in the construction industry and about 58,000 of CMs registered with the Construction Industry Development Board (CIDB), Malaysia [7]. Since the key person in construction and generally representing the contractors are CMs, their contributions towards the successfulness of construction projects are undeniable, particularly during the construction phase. Given that construction phase exploits a lot of resources (manpower, materials, money, and machines), a competent CM is needed in order to manage those resources and geared up to achieve organizational objectives. Unfortunately, in reality only a few CMs are qualified and fully trained. Even within the 58,000 CMs, their level of competencies and qualifications are unknown. This mismatch together with problems of poor site management have resulted in many construction projects' failures and end up derailed from their true goals.

The issue underpinning the lack of trained and competent CMs is the dearth of recognized and established term of references for competency provided within the industry as highlighted by several researchers $[2,8,9]$. They collectively agreed on alleviating construction personnel's technical and managerial skills where gaps are still persisting. Thus, a review on the common area of problems shows that the predicament stems from the curriculum development process where the 
essential part lies in the contents generation, which fundamentally related to the competency identification. It is apparent that the lack of terms of reference on the generic technical competency for CM has been the major setback. Therefore, this paper reports a preliminary study which aimed at identifying the technical competencies of CM.

\section{Construction management and competency}

Koskela [10] stated that construction management process is "where the detail designed is transformed into a construction/fabrication plan and into day-to-day coordination and control of processes on site or in a factory". It generally focuses on the tendering process where a contractor starts to get involved in the bidding activity until the close-out phase $[11,12]$. Therefore, construction management covers all processes including the off-site activities (i.e. tender) and the on-site activities (i.e. construction at site, inspection, and operation). The demanding nature of the construction phase necessitates an all around capable manager to lead and serve as moderator between each parties involved [13,14]. It is well accepted that the roles and tasks of CMs would significantly determine the successfulness of a project. Thus, culmination of views from a number of researchers are summarized and tabulated as shown in Table 1.

Table 1: Characteristics of construction management

\begin{tabular}{|l|l|}
\hline \multicolumn{1}{|c|}{ Item } & \multicolumn{1}{c|}{ Construction Management } \\
\hline Period & Have definite start and end \\
\hline Phases & From advertise notice to bidders, to inspection \& acceptance of project \\
\hline Product & Unique development for new or existing building \\
\hline Main Resources & Manpower, materials, machines, and money \\
\hline Purpose & Specific (meet client's requirements) \\
\hline Function & Appropriate management functions \\
\hline Medium & Appropriate knowledge, skills, tools, and techniques \\
\hline Environment & Complex, dynamic, uncertain \\
\hline Key Parties & Contractors \\
\hline Main Activities & Tendering (from bidding), overall construction period (according to \\
\hline
\end{tabular}

Both Hassan et. al. [15] and Stoof et. al. [16] agreed that the concept of competency is frequently used in the area of education including training and Continuing Professional Development (CPD). In particular, this concept is deemed to be the underlying formula to develop a new educational methods or improvisation of an existing method. According to Cambridge Advance Learner's Dictionary [17], competency (or competence) means "the ability to do something well" or "an important skill that is needed to do a job". Nevertheless, the concepts of competency were portrayed differently by several researchers $[15,16,18,19]$. It is obvious that the concept of competency underpinned the definition propounded by the researchers. However, it is noticeable that skills, knowledge, and abilities (including attitudes) become the primary elements when discussing what is inside the "competency". Hassan et. al. [15] stressed that competency is a combination of technical (hard skills and knowledge) and behavioural/non-technical (soft skills and abilities). In contrast, both Stoof et. al. [16] and Deist et. al. [19] agreed mutually on the visible part of competency which comprises of hard skills and knowledge. This is due to the fact that hard skills and knowledge are noticeable and also teachable, and are categorized as hard competency and able to be developed through training and education.

\section{Methods of Research}

This study embarked in exploratory mixed methods, comprising literature review and structured interview. In literature review processes, identification of technical competencies for CM employed a multi-layered thematic process to ensure reliability of literature analysis, where multiple considerations' loop was prepared so that the findings could be considered to be exhaustive and holistic (see Figure 1). As far as the objective is concerned, the basis of construction phase and Isa's 
work on validation of CM's competency to anchor the subsequent processes were inevitably assisting the literature analysis to be conducted manually [14]. Similar to Isa's approach, this research study also adopted the worker-oriented attribute based competency identification. It is believed that the approach can be generalized throughout the construction management phase; despite different techniques of construction method are applied.

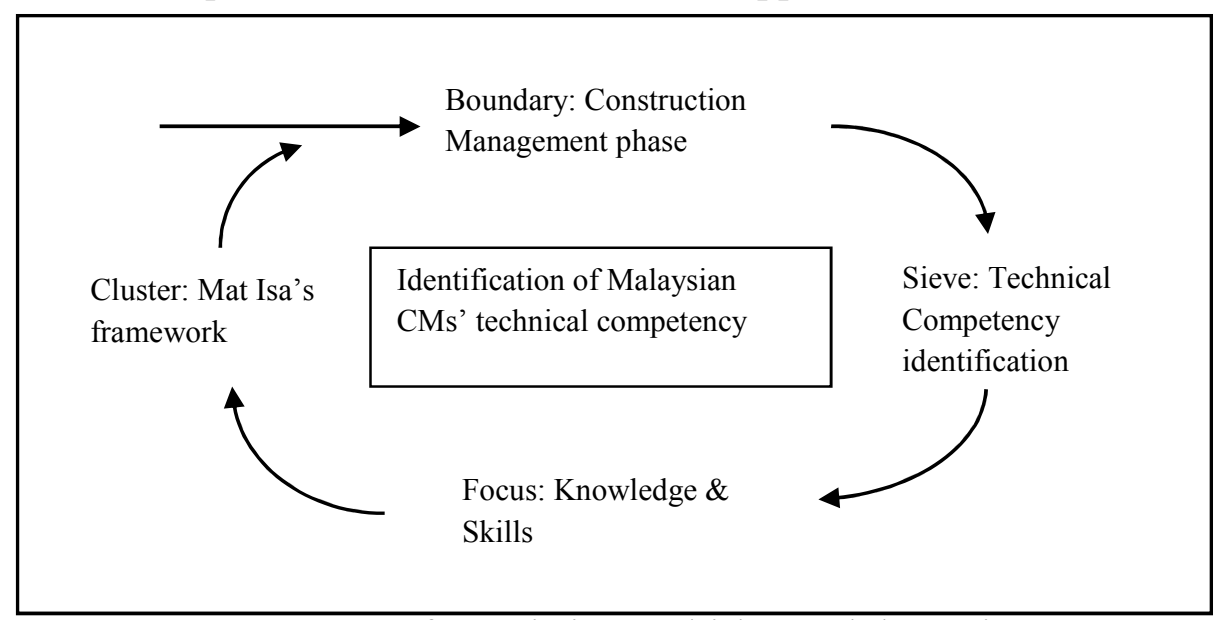

Figure 1: Loop for assisting multi-layered thematic process

The technical competencies were gathered from several literature and researchers $[2,13,14,20$ 31]. A matrix table was prepared to assist the competency classification. It was then followed by the table of knowledge and skills categorization (refer to Table 2).

Structured interview was then utilized to explore central phenomenon and validate CM's technical competencies as identified from literature analysis through the multi-layered thematic process. The respondents were purposely selected to fit the outlined criteria including their current position in the organization, their cumulative experience where the benchmark is 10 years and more, and their availability. The interview questions were of open-ended format so that respondents can share their opinions without any constraints whatsoever. In view of the fact that the prepared questions were leaning to seek confirmatory on the observed technical competencies, data were recorded by using pen and paper before further transcribed and typed them into a computer file for analysis. After that, an analysis was done manually with minimal thematic analysis effort since most respondents posed similar opinions and the summary of results was tabulated.

\section{Results and Discussion}

Since technical competencies of CM are essential in this study, multiple perspectives should be considered which include the establishment of the boundary of construction management for initial screening process, the technical knowledge and skills related to technical competency of CM, and finally clustering approach to segregate each group of technical competencies. Therefore, Table 2 outlines the summary of identified CM's technical competencies from the literature analysis employing multi-layered thematic techniques. Three layers of technical competencies were proposed namely macro level, meso level, and micro level. However, only details up to meso level are tabulated here basically based on the items stated in the structured interview. The segregation of technical competencies by using clustering approach offers simplistic and perceptive views, where elements within each cluster can be seen clearly.

As for the structured interview, a total of nine so called experts were interviewed comprising two academicians, one academician/practitioner, and six practitioners. All academicians were senior staff in the field of Construction Management; while all practitioners were also senior professionals in their respective construction companies (i.e. one Contract Manager, one Project Manager, one Engineer, and three CMs). Although there was no specific number of respondents required to obtain satisfactory saturation point, the research had taken an extended efforts to interview nine experts in 
order to confirm the consistency of results. All results were manually analyzed by theme approach and further simplified as tabulated in Table 3 to ease understandings.

Table 2: CM's technical competencies - differentiation between macro level, and meso level

\begin{tabular}{|c|c|c|}
\hline \multicolumn{2}{|c|}{ Macro Level } & \multirow{2}{*}{ Meso Level } \\
\hline Cluster & Elements & \\
\hline \multirow{8}{*}{ RESOURCES } & Staff & Knowledge and skills of staff management (including their development, welfare, laws, \\
\hline & \multirow{2}{*}{ Materials } & Knowledge of construction materials (concrete, steel, wood, soil, etc.). \\
\hline & & Knowledge and skills of material management (including their procurement, logistics, \\
\hline & Labour & Knowledge and skills of labour management (including their productivity, welfare, \\
\hline & \multirow{2}{*}{ Plant / equipment } & Knowledge of construction plant/equipment and their utilization. \\
\hline & & Knowledge and skills of plant management (including their requisition, maintenance, \\
\hline & \multirow{2}{*}{$\begin{array}{l}\text { Sub- contractor } \\
\text { (including NSC) }\end{array}$} & $\begin{array}{l}\text { Knowledge and skills of sub-contractor management (including their claims and } \\
\text { payments, variations, insurances, etc.). }\end{array}$ \\
\hline & & $\begin{array}{l}\text { Knowledge and skills of sub-contractor tendering and bidding (procedures, pretender, } \\
\text { bid analysis, quantity take-off, etc.). }\end{array}$ \\
\hline \multirow{9}{*}{ OBJECTIVES } & \multirow{3}{*}{ Safety } & Knowledge of health and safety equipments and manual. \\
\hline & & $\begin{array}{l}\text { Knowledge and skills of health and safety management (including their practices, } \\
\text { compliance, regulation, training, etc.). }\end{array}$ \\
\hline & & Knowledge and skills of risk management (including their assessment and analysis, \\
\hline & Money & $\begin{array}{l}\text { Knowledge and skills of financial and cost management (including their claims and } \\
\text { payments, pricing and purchasing practice, etc.). }\end{array}$ \\
\hline & \multirow[b]{2}{*}{ Quality } & Knowledge of construction specifications, TQM, building codes and standards, etc. \\
\hline & & $\begin{array}{l}\text { Knowledge and skills of quality management (including their administration, } \\
\text { assurance, quality control, etc.). }\end{array}$ \\
\hline & Time & $\begin{array}{l}\text { Knowledge and skills of time management (including understanding of project } \\
\text { scheduling, updating, etc.). }\end{array}$ \\
\hline & \multirow{2}{*}{ Environment } & $\begin{array}{l}\text { Knowledge and skills of environment management (including their assessment, } \\
\text { Environment Management System (EMS), etc.). }\end{array}$ \\
\hline & & $\begin{array}{l}\text { Knowledge of green and sustainable construction (including Green Building Index } \\
\text { (GBI), green construction techniques, etc.). }\end{array}$ \\
\hline \multirow{14}{*}{$\begin{array}{c}\text { GENERAL } \\
\text { CONSTRUCTION } \\
\text { MANAGEMENT } \\
\text { TASK }\end{array}$} & Administration & $\begin{array}{l}\text { Knowledge and skills of construction administration (including documentation and } \\
\text { record, submissions, plans/drawings, meeting, etc.). }\end{array}$ \\
\hline & \multirow{9}{*}{ Pre - construction } & Knowledge and skills of construction site surveying, site layout, temporary \\
\hline & & $\begin{array}{l}\text { Knowledge and skills of construction site management (including overall resources } \\
\text { management, master programme, construction sequences, Work Breakdown Structure, }\end{array}$ \\
\hline & & Knowledge of civil/structural design. \\
\hline & & Knowledge of construction systems (including Industrialized Building System (IBS), \\
\hline & & Knowledge of mechanical and electrical systems. \\
\hline & & Knowledge of quantity surveying. \\
\hline & & $\begin{array}{l}\text { Knowledge of Value Engineering (eliminating unnecessary cost which does not } \\
\text { contribute to the value of construction). }\end{array}$ \\
\hline & & $\begin{array}{l}\text { Knowledge of Constructability (analysis of construction coordination issues associated } \\
\text { with various trades). }\end{array}$ \\
\hline & & Knowledge of Lean Construction (application of production management to \\
\hline & $\begin{array}{l}\text { Closeout \& } \\
\text { handover }\end{array}$ & $\begin{array}{l}\text { Knowledge and skills of construction closeout and handover procedures (including } \\
\text { their management, commissioning, acceptance, transfer, etc.). }\end{array}$ \\
\hline & Responsibilities to & Knowledge and skills of construction law and legislation (including authorities \\
\hline & third parties, main- & Knowledge and skills of construction businesses (sales, commercial, trades, economic \\
\hline & $\begin{array}{l}\text { clerk of work \& } \\
\text { designer }\end{array}$ & $\begin{array}{l}\text { Knowledge and skills of administering and assisting/facilitating client, senior manager } \\
\text { and junior manager (including their coordination, liaison of works, orders, etc.). }\end{array}$ \\
\hline & & $\begin{array}{l}\text { Knowledge and skills of general computer application (MS Excel, MS Office, Adobe, } \\
\text { internet based, etc.). }\end{array}$ \\
\hline OVERALL & Computer \& IT & $\begin{array}{l}\text { Knowledge and skills of construction information technology / software application } \\
\text { (MS Project, Primavera, CAD, scheduling, estimating, accounting, etc.). }\end{array}$ \\
\hline & $\begin{array}{l}\text { Construction } \\
\text { contract }\end{array}$ & $\begin{array}{l}\text { Knowledge and skills of construction contracts (including their administration, } \\
\text { document, variations, Extension of Time, claims and payments, subcontracts, conflicts, }\end{array}$ \\
\hline
\end{tabular}


Table 3: Summary of comments from the observed technical competencies for CM

\begin{tabular}{|c|c|c|c|c|c|c|c|c|c|}
\hline \multirow{2}{*}{ Questions } & \multicolumn{3}{|c|}{ Academician } & \multicolumn{3}{|c|}{ CM } & \multirow{2}{*}{$\begin{array}{l}\text { Project } \\
\text { Manager }\end{array}$} & \multirow{2}{*}{$\begin{array}{l}\text { Contract } \\
\text { Manager }\end{array}$} & \multirow{2}{*}{ Engineer } \\
\hline & I & II & III & I & II & III & & & \\
\hline $\begin{array}{l}\text { Does the macro level, meso level, } \\
\text { and micro level of technical } \\
\text { competencies for CM cover } \\
\text { holistic knowledge and skills? }\end{array}$ & Yes & Yes & Yes & Yes & Yes & Yes & Yes & Yes & Yes \\
\hline $\begin{array}{l}\text { Are there any additional technical } \\
\text { competencies need to be added? }\end{array}$ & $\begin{array}{l}\text { Consideration } \\
\text { for Nominated } \\
\text { Sub-Contractor } \\
\text { (NSC) }\end{array}$ & $\begin{array}{l}\text { Consideration for } \\
\text { Nominated Sub- } \\
\text { Contractor (NSC); } \\
\text { Consideration for } \\
\text { wastages (from } \\
\text { materials, labours, } \\
\text { etc.) }\end{array}$ & No & No & No & No & No & No & No \\
\hline
\end{tabular}

\section{Conclusion}

This paper has reported results of a preliminary study on identifying technical competencies specifically for the CM. The multi-layered thematic literature analysis approach employed, and later verified by structured interview, was believed to be exhaustive, holistic, and comprehensive enough as a term of reference for multiple purposes. Thus, it has been proven that the findings were reasonably reliable. However, it is crucial to investigate further by conducting mass questionnaire survey to evaluate and analyze indigenous contractors' perception/opinion towards the importance of such technical competencies of CM. All feedbacks from the structured interview should be analyzed and critically taken into considerations when developing the questionnaire survey items/scripts. This extended effort also serves as an endeavour to validate and generalize the consistency of the findings to the masses (i.e. respondents from a reasonable number of contracting companies throughout Malaysia).

\section{References}

[1] Construction Industry Development Board Malaysia. (2012). Retrieved 6 1, 2012, from Intranet: http://intranet.cidb.gov.my/iso_diy/consultant.nsf/cons_publish?OpenView\&Start=1.

[2] Ibrahim, A. R., Roy, M. H., Ahmed, Z., \& Imtiaz, G. (2010). An Investigation of the Status of the Malaysian Construction Industry. Benchmarking: An International Journal, pp.294-308.

[3] Sambasivan, M., \& Soon, Y. W. (2007). Causes and Effects of Delays in Malaysian Construction Industry. International Journal of Project Management, Vol. 25 , pp.517-526.

[4] Abdul Rahman, H., Berawi, M. A., Berawi, A. R., O. Mohamed, M. O., \& Yahya, I. A. (2006). Delay Mitigation in the Malaysian Construction Industry. Journal of Construction Engineering and Management, 132(2) , pp.125-133.

[5] Jabatan Audit Negara Malaysia. (2010). Laporan Ketua Audit Negara Tahun 2010: Aktiviti Kementerian/Jabatan dan Pengurusan Syarikat Kerajaan Persekutuan. Kuala Lumpur: Jabatan Audit Negara Malaysia.

[6] Unit Penyelarasan Pelaksanaan. (2013, May 27). Pengurusan Projek Sektor Awam. Bengkel Penggubalan Modul Dan Kaedah Pelaksanaan Kursus Pensijilan Pengurusan Projek Sektor Awam . Kuala Lumpur, Malaysia: Jabatan Perdana Menteri.

[7] Construction Industry Development Board Malaysia (CIDB). (2011). Buletin Statistik Pembinaan Suku Tahunan 2011. Quaterly Report, pp. Suku 4, Bahagian 1.

[8] Hassan, F., Maisham, M., Khan, S. M., Alwi, S. A., \& Ramli, H. (2010). Competencies, Skills, and Knowledge of Quantity Surveying Graduates. The Quantity Surveying International Convention.

[9] Bakar, A. H. (2009). Construction in the Developing World: Issues on Indigenous Contractors. In A. S. Hassan, Contextual Issues of the Built Environment in Malaysia (pp. 27-59). Pulau Pinang: Penerbit Universiti Sains Malaysia. 
[10] Koskela, L. (1992). Technical Report No. 72: Application of the New Production Philosophy to Construction. Stanford University: Centre for Integrated Facility Engineering.

[11] National Center for Construction Education and Research (NCCER). (2008). Project Management: Annotated Instructor's Guide, $2^{\text {nd }}$ Edition. New Jersey: Pearson, NCCER, Contren Learning Series.

[12] Halpin, D. W. (2006). Construction Management, $3^{\text {rd }}$ Ed. Hoboken, NJ: John Wiley \& Sons, Inc.

[13] Farooqui, R. U., \& Saqib, M. (2010). Desirable Attributes and Skills for Graduating Construction Management Students. Associated Schools of Construction Proceedings, 46th Annual International Conference.

[14] Isa, S. S. (2007). A Study on Roles and Tasks of Construction Managers in Malaysian Construction Industry. Unpublished M.Sc. Thesis . Shah Alam: Universiti Teknologi Mara Malaysia.

[15] Hassan, F., Samad, Z., Hassan, S., Che Mat, M., \& Isnin, Z. (2010). Training the Construction Workforce: A Case Study of Malaysia. Conference Proceeding W089 - Special Track 18th CIB World Building Congress, (pp. 230-241).

[16] Stoof, A., Martens, R. L., Merriënboer, J. J., \& Bastiaens, T. J. (2002). The Boundary Approach of Competence: A Constructivist Aid for Understanding and Using the Concept of Competence. Human Resource Development Review , 1, 345.

[17] Cambridge Advanced Learner's Dictionary. (2008). $3^{\text {rd }}$ Ed. Cambridge University Press.

[18] Dogbegah, R., Owusu-Manu, D., \& Omoteso, K. (2009). A Principal Component Analysis of Project Management Competencies for the Ghanaian Construction Industry. Australasian Journal of Construction Economics and Building, 11(1), pp.26-40.

[19] Deist, F. O., \& Winterton, J. (2005). What Is Competence? Human Resource Development International , 8(1), pp.27-46.

[20] Construction Management Association America (CMAA). (n.d.). CMAA: Advancing Professional Construction and Program Management Worldwide. Retrieved June 25, 2014, from https://cmaanet.org/competencies.

[21] Benhart, B. L., \& Shaurette, M. (2011). Establishing New Graduate Competencies: Ensuring that Construction Management Curriculums are Delivering "Job-Ready" Employees. 47th ASC Annual International Conference Proceedings.

[22] Lee, N., Ponton, R., Jeffreys, A., \& Cohn, R. (2011). Analysis of Industry Trends for Improving Undergraduate Curriculum in Construction Management Education. 47th ASC Annual International Conference Proceedings.

[23] Wandahl, S. O., \& W. Ussing, L. (2010). Construction Management Engineer Education with Focus on Competencies Required by the Construction Industry. Conference Proceeding W089 - Special Track 18th CIB World Building Congress, pp.1-10.

[24] Mullin, P. T., \& N. Williams, A. (2010). Using Skills Gap Analysis in Construction Management to Stimulate a Demand led Model of Curriculum. Conference Proceeding W089 - Special Track 18th CIB World Building Congress, pp.65-79.

[25] Ahn, Y. H., Kwon, H., Pearce, A. R., \& Shin, H. (2010). Key competencies for US construction graduates: an exploratory factor analysis. ASC Proceedings of the 46 th Annual Conference.

[26] Koch, D. C., \& Benhart, B. (2010). Redefining Competencies for Field Supervision. ASC Proceedings of the 46th Annual Conference.

[27] Arditi, D., Ongkasuwan, D., \& Institute, t. C. (2009). Technical Notes: Duties and Responsibilities of Construction Managers: Perceptions of Parties Involved in Construction. Journal of Construction Engineering and Management, 135(12).

[28] Fester, F. C. \& Haupt, T. C. (2008). Capstone Courses as the Vehicle to Employability Improvement of Construction Graduates. Proceedings of the International Conference on Building Education and Research (BEAR). 
[29] Gunderson, D. E. (2008). Ranking Construction Superintendent Competencies and Attributes Required for Success. Proceedings of the 44th Annual Associated Schools of Construction Conference. Auburn, Alabama: Auburn University.

[30] Waluyo, R. (2007). Pendidikan Profesional Konstruksi di Indonesia. Jurnal Teknik Sipil, 8(1), pp.23-36.

[31] Souder, C., \& Gier, D. M. (2006). What does the Construction Industry expect from recent Construction Management Graduates? ASC Proceedings of the 42nd Annual Conference. 